\title{
HIERARQUIA ECLESIÁSTICA E PREGAÇÃO NA PROVENÇA DO SÉCULO V*
}

\author{
ECCLESIASTICAL HIERARCHY AND PREACHING \\ IN PROVENCE IN THE FIFTH CENTURY
}

\author{
Rossana Alves Baptista Pinheiro ${ }^{* *}$ \\ rossana.unifesp@gmail.com
}

RESUMO: Este artigo propõe-se a uma reflexão sobre as interações entre clérigos e laicos na Provença no século V. Toma-se como ponto de partida, em primeiro lugar, a constituição dos monges como um tipo especial de laico e, em segundo, a pregação como função própria a padres integrantes, ao mesmo tempo, da hierarquia eclesiástica e membros do monacato. Tomamos como documentos para análise alguns livros das Instituições cenobíticas e das Conferências de João Cassiano, bem como hagiografias e textos de elogios produzidos por monges da Abadia de Lérins.

PALAVRAS-CHAVE: Hierarquia eclesiástica; monarquismo; pregação.

ABSTRACT: This article proposes a reflection on the interactions between clergy and laity in Provence during the fifth century. As a starting point, I will present monks as special kind of laity and, second, the preaching as priests' function while they were monks and also members of the ecclesiastical hierarchy. To do this work, I analyse two of John Cassian's work, Intitutions cénobitiques and Conférences, but also some hagiographies and texts of praise produced by monks of Lérnis' Abbey.

KEYWORDS: Ecclesiastical hierarchy; monarchism; preaching.

\footnotetext{
* Parte dos resultados apresentados aqui foi objeto de conferência proferida no I Colóquio Internacional "Clérigos e laicos: interações na Idade Média e no Renascimento", na Universidade Federal de Goiás, em agosto de 2012. ** Doutora em História. Professora do Departamento de História da Universidade Federal de São Paulo -
Unifesp.
} 


\section{APRESENTAÇÃO DA PROPOSTA}

O tema da interação entre clérigos e laicos durante a Idade Média é deveras instigante e estimulante para a abordagem da Antiguidade Tardia, uma vez que demanda a necessidade de se traçar um caminho investigativo novo, mas também arriscado e fadado ao fracasso. Digo isto porque, entre os séculos II e VI d.C, talvez não encontremos uma documentação que permita a realização de uma reflexão sobre o laicato como categoria oposta ou inferior à dos clérigos. Esta possível ausência talvez possa ser explicada por termos ainda neste período um esforço de consolidação de uma estrutura eclesiástica hierárquica encabeçada pelo episcopado, iniciada já no século II d.C, como nos informam obras de Inácio de Antioquia e de Irineu de Lyon, mas que no século $V$ d.C, ainda não estaria concluída e consolidada. Todavia, a despeito das dificuldades que a temática impõe arriscar-me-ei a traçar um percurso que permita pensar a fluidez entre as fronteiras entre clérigos e laicos durante a Antiguidade Tardia. Este artigo buscará, portanto, explorar as possibilidades de se pensar as interações entre clérigos e laicos na Provença e, mais especificamente, em Marselha e em Lérins, durante o século $V$ d.C (419-450). Dois movimentos serão levados em consideração: por um lado, o lugar ocupado por um tipo "especial" de laico - os monges -, segundo os escritos de um dos principais teóricos do monaquismo no Ocidente. Refiro-me a João Cassiano e à hereditariedade apostólica que concedeu aos monges egípcios e, por consequência, aos monges situados na Provença. Se levarmos em conta a ideia de André Vauchez (VAUCHEZ, 1995), segundo a qual, a interação entre clérigos e laicos poderia ser buscada no encontro entre doutrina e disciplina, ou na prática cotidiana de preceitos determinados, abrimos um caminho de investigação, ao aguçarmos o olhar para a consolidação do monaquismo e da hierarquia eclesiástica, ainda que não tenha sido este o caminho escolhido por Vauchez. Procurarei apresentar, como João Cassiano articulou doutrina, disciplina e hierarquia ao teorizar sobre o monaquismo, conferindo-lhe, segundo afirmado por Adalbert de Vogüé (DE VOGÜÉ, 
1961), uma estrutura "quase-eclesiástica" e, talvez, concorrente ao episcopado. Por outro lado, abordarei a pregação, que, apesar de ser considerada parte da função episcopal, foi, na Provença, praticada por monges de Lérins, sobretudo por aqueles que ocupavam um lugar na hierarquia eclesiástica, ao integrarem o presbiterato. Esta prática ocasionou uma inversão, ou mesmo uma subversão, na hierarquia eclesiástica e acabou por ser normatizada no Concílio de Vaison de 529, como pretendo apresentar ao longo deste artigo. Portanto, procurarei abordar as interações entre clérigos e laicos na Provença do século $V$ recorrendo a estas duas "singularidades": um laico de tipo especial, situado em uma estrutura "quase eclesiástica", que possuía a legítima hereditariedade apostólica no que dizia respeito à doutrina e à disciplina; e a prática da pregação presbiteral.

\section{MONAQUISMO, HIERARQUIA E EXPERIÊNCIA SEGUNDO JOÃO CASSIANO}

Em 1934, Irinée-Henri Marrou (MARROU, 1934) publicava um artigo no qual propunha a apresentar a evolução de dois termos fundamentais para a constituição do latim eclesiástico e do próprio pensamento dos autores latinos entre os séculos III e VI: "doutrina" e "disciplina". Segundo o autor, estas duas palavras estavam tão interligadas entre si, que se tornava difícil defini-las separadamente. Isto decorria do fato de ambas terem a mesma raiz: didaché, ou, mais especificamente, docere/discere. Ambos os termos remeteriam à relação existente entre mestres e discípulos, fundamental para a transmissão de uma ciência. Agostinho, por exemplo, teria usado "doutrina" para se referir ao ensinamento transmitido por um mestre, e "disciplina" para falar da matéria específica que resultaria em conhecimento. "Disciplina" teria o sentido de educação, em correspondência direta ao termo grego paideia. Neste sentido, não só um sentido intelectual estaria agregado ao termo, mas seu aspecto moral seria apresentado quando se fazia um uso de tal 
termo. "Disciplina" remeteria à aquisição de um método, de preceitos e regras impostas por um mestre aos discípulos, fornecendo um caráter prático ao ensino, uma passagem da teoria à ação.

Também Mary Carruthers tratou de "disciplina" a partir do vínculo com a experiência e da criação de um caminho a ser percorrido para o aprendizado de um conhecimento. Em sua obra dedicada à técnica da memória na retórica monástica, a autora alertou para o fato de que:

[...] embora a palavra disciplina não tenha sido vinculada pelos antigos gramáticos a palavras com o significado de 'rota' ou 'trajeto', pensava-se que ela fosse derivada do verbo discere, 'aprender'. E, dado que a educação antiga era modelada fundamentalmente como 'caminhos' e 'rotas', o trivium e o quadrivium das artes, os discípulos são aqueles que percorrem os trajetos marcados pelas experiências práticas de seus mestres e ancestrais (CARRUTHERS, 1998, p. 119120).

Para além das noções de doutrina e disciplina estarem estreitamente vinculadas a certa noção de "educação" e aprendizado, não podemos deixar de levar em consideração que tais termos também envolvem uma questão de autoridade e de poder, à medida que a legitimidade da transmissão do conhecimento estaria atrelada à experiência, ou seja, ao mestre que poderia ensinar por ter ele próprio aprendido, o que the conferia autoridade e legitimidade para proferir a doutrina. Tais perspectiva e articulação são encontradas nos escritos de João Cassiano, dedicados não só a fornecer normas de conduta e garantir preceitos para a condução do modo de vida monástico, mas, sobretudo, a dar aos monges um lugar no universo eclesiástico, uma vez que escreveu e dedicou suas obras a bispos e a monges que alcançaram o episcopado das mais importantes dioceses da Gália.

Segundo Columba Stewart (STEWART, 1988), João Cassiano teria nascido em 360, em uma cidade situada entre o Danúbio e o Mar Negro, caracterizada pelo bilinguismo greco-latino. Segundo seu próprio testemunho, teria nascido em uma família com condições de the fornecer uma educação nas letras clássicas (JEAN CASSIEN, 24.1.3, 1959, vol III) e, por 
isto, estudara literatura, poesia e histórias épicas com um pedagogo (JEAN CASSIEN, 14.1.2, 1959, vol II). Em 380, deixaria sua família para, juntamente com Germano, partir à Belém, com a disposição de vivenciar o monaquismo palestino. Mas os dois não ficariam muito tempo neste mosteiro localizado perto de onde Cristo nascera e, no qual, passariam a primeira infância na religião (JEAN CASSIEN, 3.4, 2001). De lá, partiriam para o Egito, onde conheceriam comunidades monásticas na Cétia, na Nítria e em Quélia. Foi esta vivência que Cassiano valorizou ao escreveu duas de suas principais obras, dedicadas a bispos e monges da Gália, e nas quais podemos encontrar, ainda que de modo implícito, suas considerações sobre o lugar ocupado pelo monaquismo, sua hereditariedade apostólica e sua correspondência a uma estrutura "quase" eclesiástica, já que possuidora de hierarquia, disciplina e doutrina.

A primeira referência à hereditariedade apostólica do monaquismo egípcio aparece logo no prefácio de As instituições cenobítica. Dedicada ao bispo de Apt, Castor, João Cassiano afirma que a região da Viennense, a qual pertencia a diocese de Apt, não possuía monastérios, e isto tornava louvável a iniciativa fundadora de Castor. Mais louvável era, ainda, por desejar que tal monastério fosse regido por princípios e pelo modo de vida dos egípcios. As supressões, acréscimos ou ajustes que João Cassiano faria às constituições monásticas recentes que encontrara na Gália teriam como parâmetro sua vivência e experiência junto aos monges do Egito e da Palestina. Como justificativa, Cassiano apontava:

Pois não acredito em absoluto que uma fundação recente pôde encontrar nas regiões ocidentais da Gália qualquer coisa de mais razoável e mais perfeita do que estas instituições segundo as quais permanecem até nós desde o início da pregação apostólica os mosteiros fundados pelos Pais santos e espirituais (JEAN CASSIEN, Praef. 8, 2001).

Com isto, Cassiano já apontava a linha argumentativa que o conduziria até o final da escrita de suas duas obras: a tradição monástica oriental, e, mais especificamente egípcia, deveria ser trazida e respeitada na Provença, pois suas doutrinas e instituições remontavam aos Apóstolos em uma cadeia 
sucessória ininterrupta.

No segundo livro de As Instituições cenobíticas, esta questão é retomada em decorrência da explicação sobre as razões pelas quais, entre monges orientais, fora fixado o número de doze salmos para serem cantados durante a noite, em detrimento de outras possibilidades numéricas igualmente existentes ${ }^{1}$. Tal variedade normativa apontava para a existência de um auto governo condenável por Cassiano, pois demonstrava que as normas eram estabelecidas em conformidade com a vontade de cada monastério e não em obediência à autoridade do preceito (JEAN CASSIEN, II.2, 2001). Nas regiões do Egito e da Tebaida, ao contrário, a prática dos doze salmos não derivava sua autoridade da iniciativa humana, visto que estava enraizada alhures. Valendo-se de uma confluência de tradições textuais, como a Vida de Pacômio e a Historia Eclesiástica de Eusébio de Cesareia, citada, inclusive, explicitamente, João Cassiano explicou que, no início da fé, um pequeno número de homens chamados monges (monachus), havia recebido suas normas de vida do Evangelista Marcos, primeiro bispo de Alexandria. Não satisfeitos em cumprir as práticas que eram as da Igreja Primitiva, determinadas nos Atos dos Apóstolos, estes homens aperfeiçoaram práticas já sublimes. Retiraram-se para lugares afastados para levarem um gênero de vida austero, baseado na abstinência. Dia e noite, aplicavam-se à leitura das Escrituras, à oração e ao trabalho manual:

Nesta época, na qual a perfeição da Igreja primitiva continuava inviolável entre seus sucessores, a lembrança estando ainda recente, e na qual a fé fervente do pequeno grupo não tinha ainda se enfraquecido ao se espalhar na multidão, os Pais veneráveis, velando com uma preocupação atenta sobre seus sucessores, reuniram-se para deliberar a medida a ser fixada para o culto cotidiano de todo o corpo da fraternidade. Eles acreditavam que, assim, transmitiam aos seus sucessores esta herança de piedade e de paz, ao abrigo de toda querela intestina, temendo, com efeito, nas celebrações cotidianas, que uma dissonância ou uma variedade entre homens que professavam o mesmo culto não engendrasse, no futuro, o germe do erro, da rivalidade e do cisma. (JEAN CASSIEN, II.3, 2001) 
Ainda que estivessem reunidos para fixar o número de salmos a ser cantado, os anciãos não conseguiram entrar em acordo até o anoitecer. Ao iniciarem a prática, mesmo sem terem conseguido normatizá-la, um ancião chegou até o número de doze salmos e silenciou. Desta forma, legaram à posteridade uma regra geral, que teriam considerado em acordo com o desejo divino, porque fora enviada pelo ministério de um anjo ${ }^{2}$. Encontra-se aqui a fonte de autoridade da norma, ou seja, o próprio Deus, e a forma de sua transmissão, através de um anjo, angélica para um grupo cujo nascimento remontava à pregação apostólica.

Disse que João Cassiano citou explicitamente a obra Historia Eclesiástica de Eusébio de Cesáreia para fundamentar seus apontamentos sobre o nascimento do monaquismo nos tempos apostólicos. Todavia, ao relato eusebiano, imprimiu mudanças significativas. A primeira, quando designou por monges aqueles que em Eusébio são tidos como primeiros cristãos. No segundo livro de sua obra, Eusébio (EUSÉBIO DE CESARÉIA, 2005) recorreu ao filósofo judeu Filão de Alexandria para relatar o aparecimento de comunidades cristãs no Egito após a pregação do Evangelista Marcos, fundador da Igreja de Alexandria e seu primeiro bispo. Ao grupo chamado de "terapeutas", composto por homens e mulheres, são atribuídas práticas ascéticas como despojamento material, vida isolada em campos e bosques, leitura das Escrituras, preservação de livros antigos e a continência como principal virtude e base para, por exemplo, a abstinência e o regramento alimentar. E isto, Filão teria escrito "depois de aceitar os primeiros arautos da doutrina evangélica e dos costumes que desde o princípio transmitiram os apóstolos" (EUSÉBIO DE CESARÉIA, II.17, 2005). Além disso, parece-nos que, para Eusébio, os legítimos herdeiros apostólicos e salvaguardas do ministério da palavra divina e da pregação do Evangelho não seriam os monges, nem os terapeutas, mas os bispos. É isto o que depreendemos da leitura da abertura de sua obra lida e relida ao longo da Idade Média:

É meu propósito consignar as sucessões dos santos apóstolos e os tempos transcorridos desde nosso Salvador até nós; o número e a 
magnitude dos feitos registrados pela história eclesiástica e o número dos que nela se sobressaíram no governo e na presidência das igrejas mais ilustres, assim o número daqueles que em cada geração, de viva voz ou por escrito, foram os embaixadores da palavra de Deus; e também quantos, quais e quando, absorvidos pelo erro e levando ao extremo suas fantasias, proclamaram publicamente a si mesmos introdutores de um mal-chamado saber e devastaram sem piedade, como lobos cruéis, o rebanho de Cristo (EUSEBIO DE CESAREIA, I.1, 2005).

Portanto, competia ao herdeiro apostólico não só o ministério da palavra, como também a direção e regência sobre uma comunidade. Neste sentido, a segunda mudança realizada por João Cassiano no relato eusebiano consistiu em assegurar aos abades, e não aos bispos, a capacidade de presidir uma comunidade, dando-lhes preceitos salutares de condutas, ao considerá-los os legítimos herdeiros apostólicos.

No mesmo livro segundo de As Instituições cenobíticas, João Cassiano tratou da autoridade daquele que encabeçava uma comunidade, ao apresentar os pressupostos necessários ao exercício da função abacial. Aqui também fica evidenciada a insistência de Cassiano no fato de que seria a inexperiência e o respeito à própria vontade os responsáveis pela multiplicidade de regras, em detrimento da universalidade decorrente da obediência ao ensinamento proferido pelo ancião ${ }^{3}$. Neste sentido, Cassiano apresentou a estrutura hierárquica que deveria existir na comunidade monástica, ao postular que somente poderia ser abade aquele que, em primeiro lugar, renunciasse aos seus bens, sem se vangloriar sobre as riquezas deixadas para trás ao adentrar a vida monástica. Em segundo, poderia reger aquele que houvesse aprendido a trilhar o caminho das virtudes por meio da obediência e da submissão da vontade própria. Neste sentido, somente estava apto a comandar aquele que havia reconhecido que não detinha poder sobre si mesmo e, por isso, submetera-se aos anciãos com obediência. A cadeia de aprendizagem que unia mestre a discípulos para a transmissão da doutrina só poderia ser levada adiante, portanto, através de experiência e obediência: 
Assim, ninguém é escolhido para presidir uma congregação de irmãos, aquele que deve ser posto à cabeça, se antes não aprender com obediência aquilo que o fará comandar seus subordinados, e se não adquiriu por formação recebida dos anciãos aquilo que deverá ser transmitido aos mais jovens. Bem dirigir os outros e se fazer dirigir é, eles o declaram, próprio do sábio; e eles afirmam que é o dom mais elevado e uma graça do Espírito Santo. Pois ninguém pode estabelecer preceitos salutares para seus subordinados senão aquele que antes foi instruído em todas as disciplinas das virtudes; da mesma forma, ninguém pode obedecer a um ancião, senão aquele que, repleto de temor a Deus, se tornou perfeito na virtude da humildade (JEAN CASSIEN, II.3-4, 2001, grifo nosso).

A novidade que Cassiano imprimiu à tradição que recebeu acentuou-se em sua décima oitava conferência, escrita em aproximadamente 427. Com ela, não resta dúvidas de que o marselhês transferiu para o monacato a legitimidade da sucessão apostólica ao se apoiar nos Atos dos Apóstolos, também mencionados por Eusébio de Cesaréia. Esta conferência é fundamental para a presente reflexão, uma vez que ali João Cassiano aprofundou-se na discussão sobre o lugar ocupado pelos monges, situando-os face aos chefes das Igrejas e à massa de fiéis. Da mesma forma que nas conferências anteriores, Cassiano deu voz a um ancião, escolhido em razão da vida virtuosa e de perfeição que sustentava. No caso da décima oitava, a lição é proferida pelo abade Piamum, anacoreta e padre que habitava a região de Diolcos. Sua premissa era a de que aquele que procurava se aperfeiçoar em um modo de vida deveria conhecer os fundamentos e fundadores da arte que professava. Após apresentar os quatro gêneros de vida monástica possíveis, dois aprovados e dois que deveriam ser evitados por consistirem deturpações dos primeiros (cenobitas, anacoretas, sarabaïtas e falsos anacoretas), o abade Piamum passou a tratar da história do cenobitismo, e vinculou estreitamente sua origem aos tempos da pregação apostólica e à necessidade de preservação do fervor de uma fé que esfriava na mesma proporção em que se expandia. Os preceitos para a condução da vida cristã perfeita haviam sido dados igualmente a todos os fiéis, mas preservados apenas por um pequeno grupo 
formado a partir da partilha de bens e da vida em comunidade:

Aqueles em quem ainda ardia a chama dos tempos apostólicos, fiéis às lembranças da perfeição dos dias antigos, deixaram as cidades e a companhia daqueles que acreditavam lícita, para si ou para a Igreja de Deus, a negligência de uma vida relaxada. Estabelecidos ao redor das cidades, em lugares distantes, puseram-se a praticar, privadamente e por sua própria conta, as regras que se recordavam ter sido postas pelos apóstolos para todo o corpo da Igreja. Assim tomou corpo a observância sobre a qual falam os discípulos que se retiraram do contágio do grande número. Pouco a pouco, o progresso do tempo constitui-os em categoria separada dos outros fiéis (JEAN CASSIEN, 18. 5, 1959, vol 3).

"Pouco a pouco, o progresso do tempo constituiu-os em categoria separada dos outros fiéis". Com estas palavras, poderíamos já considerar que João Cassiano defendia o isolamento destes monges dos outros fiéis e que, portanto, os destacavam do laicato, já que entre eles poderiam ser encontrados convertidos de um "paganismo inveterado" e mesmo do judaísmo. Mas, João Cassiano vai além ao propor uma distinção dos monges também em relação aos clérigos, visto que o triunfo do cristianismo ocasionara uma mácula no interior da própria Igreja, a ponto de os chefes eclesiásticos já não buscarem uma vida de perfeição condizente com a fé primitiva e permitirem também para si uma frouxidão de costumes, sobretudo no que dizia respeito à manutenção de seus bens ${ }^{4}$.

Se Adalbert de Vogüé (DE VOGÜÉ, 1961) está correto ao afirmar que João Cassiano teria sido o primeiro a postular uma linhagem ininterrupta entre Apóstolos, primeiros monges e cenobitas, acredito que imprimou uma mudança na perspectiva que considerava tal sucessão própria aos bispos para, justamente, dar um lugar ao monacato no interior da sociedade provençal. Isto porque tal hereditariedade não contemplava somente os cenobitas egípcios, mas fora estendida aos provençais, uma vez que, conforme vimos, João Cassiano apresentou-se como o porta-voz de normas e princípios egípcios na Provença, por ter sido discípulo dos mestres egípcios e ter tido a oportunidade de aprendê-las por meio da experiência. Desta forma, podemos afirmar que Cassiano não só contribuiu para 
fornecer ao monaquismo cenobítico provençal uma origem apostólica ao dar-Ihes as normas de vida egípcia, como lhe deu uma doutrina, determinou a forma de sua transmissão e revestiu a comunidade monástica de relações hierárquicas. Com isto, estes homens instruídos na "escola" ${ }^{5}$ de Deus, tornavam-se aptos a fazer o uso da palavra para explicar e ensinar as questões divinas e o faziam através de conferências e entrevistas realizadas com aqueles que desejavam iniciar-se na sublime profissão monástica ${ }^{6}$. Tornavam-se, portanto, mestres, vocábulo que, segundo Jean-Pierre Weiss (WEISS, 1997) implicava, simultaneamente, poder hierárquico e magistério. Ou seja, referia-se àqueles que estavam em posição de transmitir um ensinamento, assim como de governar uma comunidade. Portanto, abades e bispos, mas não presbíteros. Todavia, ao separar os monges da multidão dos fiéis e dos chefes da Igreja, João Cassiano deu a eles um lugar diferenciado e os constituiu como uma categoria especial de laicos, bem como mais puros e perfeitos do que bispos. Apesar de não podermos afirmar que, explicitamente, reivindicou aos monges o ministério da pregação como herança apostólica, seu "mito da origem apostólica do monaquismo" (DE VOGÜÉ, 1961) talvez tenha fornecido uma justificativa teórica à prática da pregação que envolvia presbíteros ligados à Abadia de Lérins, situada também na Provença.

\section{PREgaçÃo e PRESBiterato em LÉRINS}

Antes de me reportar ao segundo movimento que estabeleci como fundamental à reflexão que norteia este artigo, gostaria de me reter em uma questão que julgo primordial para a comprovação da hipótese acima referida: ou seja, sobre a possibilidade de que o "mito da origem apostólica" de Cassiano tenha fundamentado teoricamente a prática da pregação presbiterial provençal. É factível considerar esta hipótese porque temos notícias sobre os diálogos mantidos entre Cassiano e os monges desta Abadia situada em uma ilha nas proximidades de Cannes, 
principalmente através das dedicatórias das obras de Cassiano. Conforme já mencionado, João Cassiano escreveu a bispos ou monges que ocupariam as dioceses mais importantes da Gália. Portanto, dedicou suas obras a monges de Lérins, alguns deles presbíteros que passariam a ocupar o episcopado, outros que sequer integravam a hierarquia eclesiástica ao se tornarem bispos. Sua primeira obra, lembremos, foi dedicada a Castor, bispo de Apt. Em uma carta de 419, enviada pelo bispo de Roma, Bonifácio, aos bispos da Gália, denominada Valentinae nos contra Máximo de Valence, partidário de Prócolo de Marselha, teria aparecido o nome de Castor e de Leôncio (bispo de Fréjus), ao lado do bispo de Arles, Pátroclo ${ }^{7}$. A ligação de João Cassiano com Lérins evidencia-se nas dedicatórias de sua segunda obra, Conferências, composta em três volumes. O primeiro deles traz o referido bispo de Fréjus, Leôncio. A dedicatória a ele justificava-se em substituição a Castor, que havia encomendado a obra, mas que falecera antes de sua conclusão. Leôncio, portanto, a receberia por direito de herança, já que era irmão de Castor, pelo sangue e pela "dignidade" do sacerdócio ${ }^{8}$. É importante ressaltar que a diocese de Fréjus era aquela que detinha a jurisdição sobre a ilha de Lérins. Retomarei adiante este dado ao apresentar o conflito que envolveu o abade de Lérins e o bispo de Fréjus acerca da autoridade sobre os laicos do mosteiro. Outra pessoa nomeada na dedicatória é o irmão Heládio, possível monge de Lérins e bispo de Arles entre Pátroclo e Honorato ${ }^{9}$.

O segundo volume das Conferências permite-nos aprofundar a inserção de João Cassiano na rede leriniana. Nele, aparecem os irmãos Honorato e Euquério, ambos figuras de destaque da Abadia de Lérins. Honorato, seu fundador e primeiro abade, teria permanecido neste cargo até, aproximadamente, 427, quando foi ordenado bispo de Arles, em substituição quer a Pátroclo, quer a Heládio. Sua trajetória foi retratada por Hilário de Arles, também monge em Lérins, parente de Honorato e seu sucessor no episcopado arlesiano. Na Vida de São Honorato ${ }^{10}$, escrita em 431, Hilário narrou o estabelecimento de Honorato em Lérins quando se uniu em caridade e afeição a Leôncio de Fréjus, ainda que habitantes "das 
redondezas" tivessem pretensões para com ele ${ }^{11}$. Além de outorgar a autoridade sobre os monges de Lérins ao seu abade, Leôncio teria decidido que nenhum outro bispo, de nenhuma outra diocese, poderia reclamar autoridade sobre Lérins ${ }^{12}$. Euquério, por outro lado, ter-se-ia instalado em Lerina, juntamente com sua família. Seus dois filhos, Verano e Salônio, haviam sido educados na Abadia e tiveram como formadores Hilário, Vicente, e Salviano. Este último dedicou a obra Do governo de Deus a Salônio, demonstrando que os vínculos foram mantidos mesmo após a saída de ambos da Abadia de Lérins. Salviano tornou-se presbítero de Marselha em 432 e Salônio, bispo de Genève. Verano foi ordenado bispo de Vence e o próprio Euquério foi bispo de Lyon, a partir de 432. O terceiro volume é dedicado aos irmãos da ilha de Hyères, Joviniano, Minervo, outroLeôncio e Teodoro. Este último é saudado como construtor de cenóbios na região e foi o substituto de Leôncio no episcopado de Fréjus. Ainda mantendo relações com Hilário de Arles, durante seu episcopado em Arles, tal vínculo foi rompido com seu sucessor no episcopado arlesiano, Ravênio, em 450, em decorrência da referida disputa pela autoridade sobre os laicos da Abadia de Lérins, levada a cabo por Teodoro e o terceiro abade de Lérins, Fausto.

Fiz essa digressão não só para demonstrar as relações mantidas entre João Cassiano e os monges de Lérins, mas também para dar uma cronologia e um contexto à temática que me ocupará a partir de agora: pregação e presbiterato em Lérins. Conforme pôde ser percebido, nos decênios de 20 e 30 do século $V$, os lerinianos ocuparam um lugar de destaque, tanto pelo brilhantismo intelectual expresso nas obras que compuseram, quanto pela conquista do episcopado de dioceses por toda a Gália. Alguns deles, como Honorato, chegaram ao episcopado depois de terem ocupado uma posição na hierarquia eclesiástica como presbítero, ainda que exercendo-a apenas dentro do mosteiro. Sobre outros, como Hilário de Arles e Euquério de Lyon, não temos informações mais precisas, o que leva a pensar que talvez tenham sido eleitos para o episcopado, tendo participado, apenas, de uma categoria especial do laicato - os servos de 
Deus, ou monges, mas não necessariamente integrados à hierarquia eclesiástica, conforme já foi mencionado. Outros ainda, tais quais Vicente de Lérins e Salviano, mantiveram-se na função de presbítero, dentro e fora da Abadia, já que Salviano saiu de Lérins para ocupar uma função na diocese de Marselha.

Neste mesmo período, a discussão sobre a relação entre monges, presbíteros e bispos, assim como a determinação da pregação como prerrogativa episcopal, apareceu em duas cartas escritas pelo papa Celestino em 428 e 431 . Na primeira, logo após a eleição de Honorato para o episcopado de Arles vale a pena sublinhar, o papa tratou da ordenação episcopal e incitou os homens da Gália a não escolherem peregrinos para o episcopado, ou seja, estrangeiros não conhecidos, que não fossem seus concidadãos $^{13}$. Talvez não tenha sido coincidência o fato de Hilário ter lançado a questão, em 431: "Mas de onde vem, então, eu vos pergunto, que de tão longe procuramos um homem tão pouco conhecido?" ao se referir à eleição de Honorato ao episcopado de Arles ${ }^{14}$. Ademais, a carta de Celestino demonstrava a inquietação do papa por este "novo colégio de onde se tiram os bispos"15, existente na Provença. A crítica papal concentrava-se nas vestimentas usadas por clérigos provençais, provenientes do ambiente monástico como o pallium ${ }^{16}$ e o cinturão ${ }^{17}$ :

Soubemos que alguns padres do Senhor adotam modos supersticiosos, no lugar de cultivar a pureza de espírito e da fé. Mas não devemos nos surpreender que eles partam ao encontro do uso eclesiástico, pois eles não engrandecem a Igreja, mas, proveniente de outro rito, levam com eles na Igreja o que tinham em outro gênero de vida: eles se cobrem com um manto e cinturam os rins, acreditando fazer obra de fé se conformando com a Escritura, não segundo o espírito, mas segundo a letra [...]. Talvez, é verdade, esse gênero de hábito, mais conforme ao uso que à razão, deve ser guardado por aqueles que moram em lugares retirados, longe dos outros homens. Mas por que se vestir assim nas Igrejas da Gália, em substituição àquela túnica que tem sido portada pelos pontífices durante tantos anos? ${ }^{18}$

Mas não somente as vestimentas que portavam suscitaram 
críticas aos eclesiásticos provençais. Outro decreto de Celestino, de 431, escrito a pedido de Próspero da Aquitânia e Hilário ${ }^{19}$, teria ressaltado a relação mantida entre presbiterato e pregação. Segundo Jean-Pierre Weiss, a discussão apresentada por Celestino neste texto estava menos centrada no problema da pregação presbiteral do que na divulgação, por meio dela, de um ensinamento errôneo ou contrário à verdade da fé. Neste caso também, a antiguidade deveria prevalecer sobre a novidade e os bispos deveriam retomar a responsabilidade pela pregação, uma vez que:

[...] nós lemos nas Escrituras que o discípulo não deve estar acima do mestre, o que significa que ninguém deve, exceto os doutores, reivindicar o ensino" e "se eles recebem o nome de padres, que eles saibam que do ponto de vista da hierarquia, eles vos [bispos] são subordinados. Que eles saibam que àquele que dá um ensinamento ruim faz muito melhor em aprender do que ensinar (apud WEISS, 1997).

Próspero da Aquitânia e Hilário (não se trata aqui do referido Hilário, bispo de Arles) fazem sua aparição nesta história por uma razão interessante. Ambos haviam escrito para Agostinho para informá-lo que, na Provença, alguns servos de Deus tinham um posicionamento contrário ao do bispo de Hipona acerca da relação entre graça, livre-arbítrio e predestinação. Tal controvérsia ficou conhecida como semi-pelagianista, e não me alongarei aqui sobre ela. Neste momento, importa apenas indicar que na carta enviada por Hilário a Agostinho ${ }^{20}$, houve a vinculação entre os servos de Deus de Marselha e de "outros lugares da Gália"21, e o suposto erro doutrinário que divulgavam por meio da pregação. Para os mestres provençais, afirmar, durante a pregação, a predestinação de um número fixo de eleitos poderia levar à tibieza e ao relaxamento dos esforços por parte dos homens que escutavam a pregação, e ela tornar-se-ia inútil se não fosse dito que ao homem ainda restava algo a fazer para cooperar com sua salvação ${ }^{22}$.

A posição de Celestino sobre a questão apontava, portanto, para a necessidade de se manter a relação entre mestre e discípulo, com base, em primeiro lugar, na posição ocupada na hierarquia eclesiástica e, 
em segundo, na capacidade de transmitir um ensinamento considerado verdadeiro. Todavia, conforme estipulado na carta anterior, não deveria ser eleito para o episcopado homens de lugares diversos à diocese em questão, tampouco laicos, viúvos recasados, esposos de viúvas e, principalmente, os palliati, ou seja, aqueles que portavam o manto monástico, fossem eles participantes ou não da estrutura eclesiástica ${ }^{23}$. Para Celestino, os monges estavam excluídos da ordenação episcopal e, portanto, da capacidade de serem mestres e de ensinarem por meio da pregação. Tal situação deixa entrever a existência na Provença de uma ligação entre monaquismo e estrutura eclesiástica, tanto naquilo que dizia respeito à eleição de monges para o episcopado, quanto à prática da pregação ou do exercício constante da fala e do magistério antes mesmo da eleição episcopal. A prática da pregação no ambiente monástico talvez estivesse relacionada ao fato de o cenóbio ter sido caracterizado como uma escola, um espaço privilegiado para o estudo e a compreensão das Escrituras. Também devido à defesa de que, para ser cenobita, e, mais especificamente, abade, era fundamental ter sido discípulo de um mestre. Da mesma forma, para a aquisição do conhecimento das Escrituras, conforme ensinado por João Cassiano.

Outros indícios apontam para esta mesma conclusão. Em sua obra escrita em 428, 0 elogio do deserto, Euquério de Lyon defendeu a importância da passagem pelo deserto marítimo - Lérins - para a aquisição de conhecimento, de possibilidade de realizar uma correta exegese sobre as Escrituras, bem como para se tornar um pastor de povos. Ao recorrer ao exemplo de Moisés, Euquerio afirmou:

$E$, acredito, ele sugere secretamente e paralelamente pelas suas palavras que, ao entrar no deserto, deve-se desapegar dos antigos laços e das preocupações da vida, para avançar na libertação das redes anteriores, evitando sujar esse lugar. É lá que, pela primeira vez, Moisés torna-se o intérprete das conversações familiares de Deus, ele escuta suas palavras e ele $O$ responde, ele se informa sobre aquilo que deverá dizer e fazer e é instruído, ele se distrai, por uma troca mútua e como usual de discursos, com o Senhor do céu! É lá que ele retoma seu cajado, a partir de agora dotado do poder dos milagres. Ele entrou no deserto pastor de cabras, e saiu pastor de povos (SAINT 
EUCHER DE LYON, 1950, p. 72).

Também contemporâneo às cartas de Celestino, foi o elogio que Hilário de Arles produziu para Honorato em 431. Motivado pela morte daquele que era seu antecessor no episcopado de Arles, seu parente e responsável por sua conversão ao cristianismo e ao ingresso no monacato em Lérins, nesta obra, Hilário defende duas ideias importantes. A primeira é a insistência que faz em uma das características mais interessantes de Honorato: a impassibilidade. Segundo Hilário, as virtudes e os méritos que possuíra como bispo de Arles já podiam ser encontrados no abade de Lérins, bem como no jovem Honorato. Durante seu tempo de neófito, fora o reconhecimento destas mesmas virtudes por parte de seus conterrâneos que o haviam lançado para fora de sua pátria, a fim de fugir daquele amor que poderia se tornar fonte de vanglória. Exercendo a função episcopal, ele continuava a ser um monge e, monge, ele era tratado com deferência pelos bispos, pois estes não:

[...] admitiam nenhuma diferença de dignidade sacerdotal. Jamais ninguém entre os bispos teve a presunção de se considerar como um igual deste padre [...] Conservava no sacerdócio a humildade do monge com a mesma integridade que, simples monge, tinha possuído em plenitude as virtudes do sacerdócio (HILAIRE D’ARLES, 16-2.3, 2008).

Hilário eliminou por completo as fronteiras entre laicos e clérigos, ou, mais precisamente, entre monges, presbíteros e bispos. Talvez em razão das virtudes a-temporais que possuía, é que teria sido possível a Honorato transformar bestas em homens com sua pregação:

Prodigiosa e admirável metamorfose: víamos não homens mudarem para fulvos por causa da beberagem de uma Circe, mas de fulvos mudarem para homens pela palavra de Cristo como por uma beberagem de requinte doce, e isso pelo ministério de Honorato (HILAIRE D'ARLES, 17-6, 2008).

Ministério este que exercia, lembremos, como padre e abade de Lérins.

A recorrência a Moisés e Honorato como modelos de pastores de seu povo não veria um fim com a morte do fundador de Lérins e bispo 
desconhecido e estrangeiro de Arles. Também Fausto de Riez fez uso destes exemplos ao sobrepor estas duas personagens na homília que teria escrito em homenagem a Honorato. Na homília 72, Fausto teria defendido a palavra como prerrogativa do superior de Lérins e teria considerado Honorato o pastor que realizava o milagre da conversão de bestas em homens e de homens em anjos ao fazer uso da palavra ${ }^{24}$. Preservação e divulgação dos ensinamentos apostólicos por parte de monges também compuseram as reflexões deste terceiro abade de Lérins (434-462). Era ele quem ocupava o cargo quando as cartas de Celestino circularam pela Gália. Além disso, seu nome ficou vinculado às duas controvérsias as quais já me referi: ao semi-pelagianismo pelo tratado Sobre a graça que escreveu em 474, quando já era bispo de Riez e à controvérsia envolvendo a jurisdição sobre os monges de Lérins. Se a Abadia fora fundada entre 400 e 410 por Honorato em território pertencente à diocese de Fréjus, mas sem estar a ela submetida, esta situação passou a ser questionada em 450, em um conflito que envolveu o abade Fausto de Riez, seu antecessor e à época bispo de Riez, Máximo, e o bispo de Fréjus, Teodoro. A querela dizia respeito sobre quem detinha autoridade sobre os monges da Abadia de Lérins: o abade ou o bispo. Teodoro desejava assumir o controle sobre a congregação laica de Lérins, contrariando as disposições de seu antecessor, Leôncio, que dera tal autoridade ao abade, Honorato. Fausto, por sua vez, reivindicava tal autoridade para si, na qualidade de abade, reafirmando a autonomia da abadia e seu abade face ao episcopado. A disputa entre ambos resultou na excomunhão de Fausto por Teodoro e na tomada de posição a favor de Fausto por Máximo. Embora a jurisdição para a resolução da disputa fosse da província da Narbonense II, onde estavam Fréjus e Lérins, nem o bispo de Marselha, nem o de Aix pronunciou-se sobre a questão. Sendo assim, a disputa foi levada ao metropolita da Provença, o bispo de Arles, Ravênio, sucessor de Honorato e de Hilário no cargo. Coube a ele, portanto, convocar um Concílio para solucionar a disputa. A resolução foi favorável a Máximo e a Fausto. Mais do que isto. Os bispos reunidos em Arles estabeleceram a primazia monástica sobre a episcopal dentro do mosteiro, ficando Teodoro 
responsável apenas por novas ordenações eclesiásticas quando fossem requisitadas pelo abade ${ }^{25}$. Acredito que esta situação ganharia um novo contorno no século seguinte, quando, em 511, o I Concílio de Orléans, em seu cânone XIX prescreveria que:

[...] os abades, em virtude da humildade religiosa, sejam submissos à autoridade dos bispos [episcoporum potestate], e caso ajam em qualquer coisa contra a regra, que sejam corrigidos pelo bispo; que uma vez por ano eles se reúnam, sob convocação, no lugar escolhido pelo bispo. Quanto aos monges, que sejam submetidos ao abade (GAUDEMENT, 1989).

Ainda que os monges continuassem submetidos ao abade, caberia agora ao bispo zelar pela disciplina do abade e pela convocação de reuniões abaciais regulares. Mas no século $\mathrm{V}$, durante o abaciato de Fausto, coube-Ihe não só a autoridade sob seus monges, mas a possibilidade de que proferisse homilias aos monges de Lérins, dois deles panegíricos em homenagem a Honorato e a Máximo, seus predecessores. Todavia, estas homílias passaram à posteridade em uma coleção atribuída a um tal de Eusébio Galicano ${ }^{26}$.

Outro caso interessante para pensar sobre a fluidez ou a quebra de fronteiras entre monaquismo e episcopado no que tange à doutrina e legitimidade para determina-la é o de Vicente de Lérins. Ainda que tenha permanecido como presbítero em Lérins, Vicente esteve engajado na defesa da ortodoxia, ao lançar os pressupostos que pudessem diferenciá-la da heterodoxia. Temos aqui mais um exemplo de presbítero que toma para si a responsabilidade pela manutenção da doutrina por meio da exegese correta e do respeito à "tradição". Todavia, ao escrever seu Communitorium em 434, assumiu, justamente, o pseudônimo de Peregrinus, talvez em resposta direta à carta de Celestino que criticava a escolha dos peregrini, dos homens de vida retirada, para o episcopado. Além disso, foi considerado por Genádio, juntamente com Salviano de Marselha sobre quem falarei na sequência, um homem de comprovada eloquência. Segundo Jean-Pierre Weiss, Genádio teria se referido a estes dois presbíteros como magister episcoporum. Para além do fato de terem educado os filhos de Euquério, Verano e Salônio, os quais se tornaram 
bispos, Jean-Pierre Weiss considerou que o uso do termo magister aos dois presbíteros visava ressaltar a importância intelectual que possuíam em um contexto que, após a veiculação das cartas de Celestino, restringia cada vez mais a possibilidade de que presbíteros se pronunciassem sobre questões doutrinárias, sobretudo, durante a pregação, conforme vimos.

Talvez não tenha sido por acaso que o próprio Salviano, presbítero de Marselha, também tenha feito uso de um pseudônimo ao escrever seu tratado, em 434. Em sua obra intitulada À Igreja, Salviano criticou o apego à riqueza que possuíam os membros da Igreja. A despeito das semelhanças com os ensinamentos de Cassiano presentes nesta obra, como, por exemplo, a acusação que lançou sobre os dirigentes eclesiásticos de se manterem apegados aos bens, Salviano não defendeu, de maneira explícita, a ligação entre pregação apostólica e vida monástica. Ou seja, não abordou o vínculo fundamental existente entre possibilidade de usar a palavra e de viver segundo os preceitos apostólicos no ambiente monástico. No entanto, o pseudônimo que escolheu para chamar toda a Igreja a se distanciar da avareza foi o de Timóteo. Sendo assim, Salviano tomou para si mesmo a palavra ao fazer de si um Apóstolo para dizer à Igreja universal a conduta que deveria ser a sua ${ }^{27}$. Assim, sobrepondo-se ao Apóstolo ${ }^{28}$, e não como presbítero, postulou uma prática à Igreja Universal. Além disto, Salviano situou os religiosos como as pessoas que deveriam ter mais atenção ao seu modo de vida e à pobreza, já que eram eles os ministros da palavra $^{29}$. Embora a ligação entre modo de vida exemplar e ministério da palavra seja mantida, em Salviano não são os monges os seus portadores, mas o clero do qual Salviano fazia parte, ainda que o monacato tenha sido também para ele uma via de passagem obrigatória à ascensão eclesiástica.

Sucessores da palavra apostólica e continuadores de sua perfeição por meio do despojamento e da passagem pelo coenobium, os monges provençais tornaram-se conhecedores de Deus, possuidores do ministério da palavra e, com isso, afirmaram-se como aqueles que tinham a possibilidade de determinar uma conduta de vida para a comunidade cristã e de Ihes explicar as Escrituras. A prática da pregação dos padres foi 
autorizada pelo concílio de Vaison, de 529, presidido por Cesário de Arles, o último dos monges-bispos de Lérins. Seu segundo cânone determinou que:

Para a edificação de todas as Igrejas e para o proveito de todo o povo, decidimos dar o poder de pregar (uerbum faciendi) aos padres não somente nas cidades, mas também nas paróquia; se o padre, impedido por qualquer doença, não puder pregar (praedicare) por ele mesmo, os diáconos lerão as homilias dos Pais (GAUDEMENT, 1989).

Se Vaison normatizou e tornou legítima a prática da pregação presbiteral, de maneira irrestrita e independente dos bispos, resta a formulação de uma pergunta ainda não respondida: tratou-se aqui do restabelecimento oficial de um direito desaparecido desde sua condenação por Celestino ou do reconhecimento oficial da permanência de uma prática não interrupta ao longo deste século?

\section{NOTAS}

1 "Sabemos que, desta maneira, em diferentes lugares um canon diferente foi fixado, e que vimos adotar quase tantos tipos ou regras quanto mosteiros ou células visitados". JEAN CASSIEN. II.2. Institutions cénobitiques. Paris: Cerf, 1991.

2 "A partir deste momento, compreendendo que, por ensinamento de um anjo, o Senhor teria desejado fixar uma regra geral para as reuniões dos irmãos, a venerável assembléia dos Pais decide que este número seria guardado tanto nas reuniões do entardecer quanto àquelas da noite". Ibid. II.6.

3 "Tal é a razão da diversidade de tipos e de regras que vemos reivindicadas nas outras províncias: a maioria do tempo, sem ter a experiência do ensinamento dos anciãos, ousamos pegar o primeiro lugar no mosteiro, e, fazendo-nos passar por 'abade' antes de ter sido discípulos, estatuímos aquilo que nos agrada - mais inclinados a exigir as observâncias destas invenções do que a guardar a doutrina aprovada pelos anciãos". JEAN CASSIEN. Inst. II.4.

4 "Esta liberdade que acordaram por condescendência para a fraqueza da fé nascente, não deixa de contaminar insensivelmente a perfeição da Igreja de Jerusalém. Com o número de recrutados aumentando a cada dia, tanto do judaísmo quanto da gentilidade, o fervor da fé primitiva se perdeu. Não foi só a multidão de prosélitos que vimos relaxar na antiga austeridade, mas até os chefes da Igreja. 
Muitos, estimando lícito para eles mesmos a concessão feita à fraqueza dos gentios, persuadiram-se que não existia nenhum problema em preservar os bens e fortuna, tudo ao confessar a fé de Cristo". JEAN CASSIEN. Conl 18.5. Conférences. Paris: Cerf, 1959, vol III.

5 "Com esse discurso do abade Piamum, o desejo que já nos havia inspirado a deixar a escola elementar do cenóbio [coenobii scolis], para tender ao degrau superior dos anacoretas, se inflamou ainda mais". JEAN CASSIEN. Col. 18.5. Conférences. Paris: Cerf, 1959, vol. III.

6 "Também, os Pais eminentes, onde a palavra faz a trama destas conferências, se exprimem de tal maneira, e todas as coisas recebem com tais temperamentos, que elas podem ser convenientes a uma e a outra profissão (cenobítica e anacorética). JEAN CASSIEN. Praef. Conl. 18. Conferérences. Paris: Cerf. 1959, vol. III.

7 R. Goodrich. Contextualizing Cassian: aristocrats, ascetism, and reformation in fifth-century Gaul. Oxford: Oxford University Press, 2007.

8 Jean Cassien. Praef. Conl 1. Conférences. Paris: Cerf, 1959, vol. I.

9 O. Chadwick. Euladius of Arles. Journal of theological studies, 46, 1945.

10 Hilaire d'Arles. Vie de Saint Honorat. Paris: Cerf, 2008.

11 Ibid. 13.1.

12 "Sua [a da ilha de Lérins] situação isolada o convinha; ainda mais, ele estava encantado pela vizinhança de um homem santo e bem-aventurado em Cristo, o bispo Leôncio, e ligado a ele por uma profunda afeição [caritate constrictus]; portanto muitas pessoas se esforçassem para o dissuadir de um golpe de audácia tão novo. Com efeito, os habitantes das redondezas pretendiam este deserto formidável e se esforçavam, no interesse de sua fé, em fixar Honorato sobre seu território". Ibid. 15.2-3. Vie de Saint Honorat. Paris: Cerf, 2008.

13 "Não se deve dar a preferência aos estrangeiros (peregrini), vindos de fora e até então desconhecidos, em detrimento de homens que, pelo testemunho de seus concidadãos (ciuium), são meritórios". J-P. Weiss. "Le statut du prédicateur et les instruments de la prédication dans la Provence du Ve. siècle". In: M. Lauwers; R-M Dessi. La parole du prédicateur (V-XV siècles). Nice: Z Editions. Centre d'Études Médiévales. Faculté des Lettres, Arts et Sciences Humaines, 1997, p. 30.

14 Hilaire d'Arles. 25.1. Vie de Saint Honorat. Paris: Cerf, 2008.

15 R. Nouailhat. Saints et patrons. Paris: Belles Léttres, 1988, p. 170.

16 Ao descrever as vestes monásticas, João Cassiano apresenta o pallium como um 
componente fundamental. Constituído de um manto que cobria o monge no pescoço e nos ombros, ele servia como fator distintor entre as roupas monásticas e senatoriais. É fundamental então sublimar a manutenção do uso do pallium pelos bispos da Provença saídos do mosteiro de Lérins, como fator desta retomada do poder público sobre outros parâmetros daquele promulgado e reconhecido pela cultura senatorial romana. Jean Cassien. I. Institutions cénobitiques. Paris: Cerf, 2001.

17 Também no livro I das Instituições cenobíticas, João Cassiano apresenta o cinturão que o monge deveria portar e faz dele o signo da castidade monástica e deduz tal significado das Escrituras. JEAN CASSIEN. L.1. Institutions cénobitiques. Paris: Cerf, 2001.

18 apud DE VOGÜÉ, Adalbert. Histoire littperaire du mouvement monastique: l'essor de la litterature lérinienne et les écrits contemporains (420-500). Paris: Cerf, 2003, p. 195.

19 J-P. Weiss. "Le statut du prédicateur et les instruments de la prédication dans la Provence du Ve. siècle". In: M. Lauwers; R-M DESSI, op cit.

20 Hilaire."Lettre d'Hilaire". In: Aux moines d'Adrumète et de Provence. Desclée de Brouwer, 1962. Études Augustiniennes.

21 HILAIRE. 1.2. "Lettre d'Hilaire". In: Aux moines d'Adrumète et de Provence. Desclée de Brouwer, 1962. Etudes Augustiniennes.

22 "Eles acreditam que toda a humanidade se perdeu em Adão, e que ninguém pode se livrar desta perdição pela virtude de seu livre arbítrio; mas eles sustentam ao mesmo tempo a doutrina seguinte, que eles dizem ser conforme à verdade ou adaptada à pregação: quando anuncia-se aos homens decaídos, e que não se elevarão jamais por suas próprias forças, que a ocasião lhes é oferecida de se salvar, é graças ao mérito que é sua vontade, e sua fé tem a possibilidade de lhes curar, que eles obtém, com um crescimento de fé, a cura efetiva e inteira". Ibid. 1.2, grifo nosso.

23 A. de Vogüé. Histoire littéraire du mouvement monastique: l'essor de la litterature lérinienne et les écrits contemporains (420-500). Paris: Cerf, 2003, p. 197.

24 A. de Vogüé. Histoire littéraire du mouvement monastique: I'essor de la littérature lérinienne et les écrits contemporains (420-500). Paris: Cerf, 2003, v. 7.

25 "Certamente, deixe toda a multidão laica pertencer à preocupação do abade, não deixe o bispo se apropriar de nada disso para si ou presumir nenhum clérico, exceto quando requisitado pelo abade [...]. Certamente, toda a congregação laica 
pertence à livre preocupação e disposição do abade", apud R. Mathisen. Ecclesiastical factionalism and religious controversy in fifth-century Gaul. Washington: The Catholic University of America Press, 1989, p. 195-196.

26 A autoria das homilias desta coleção permanece ainda em discussão. Para JeanPierre Weiss, as homílias em honra de Máximo (35) e Honorato (72) seriam incontestavelmente de autoria de Fausto de Riez. J-P Weiss, op cit.

27 J-P Weiss, op cit.

28 "Talvez qualquer um estima que meu propósito seja até o presente bem rude. Ele é rude certamente se não contém a advertência fundada sobre a autoridade dos testemunhos sagrados. Mas eu quero bem que seja rude, se ele contém qualquer coisa da predicação apostólica nesta matéria! Ainda não acrescentarei estas palavras de Nosso Senhor, pelas quais ele declara de todo modo indigno dele qualquer um que não renuncia a tudo o que possui!". Salvien de Marseille. 1.8-37. “À I'Église". Oeuvres. Paris: Cerf, 1971-1972. Na primeira carta a Timóteo, Paulo o recomenda a exortar os cristãos ricos a não se apegaram na instabilidade da riqueza e formarem um tesouro no céu. Bíblia de Jerusalém. I Tim, 17.

29 "Mas então o que deverão fazer aqueles a quem o Cristo prescreveu o ministério da palavra? Eles desgostam a Deus, se guardam o silêncio; aos homens, se eles elevam a voz. Mas como os Apóstolos o responderam aos judeus, deve-se obedecer a Deus mais do que aos homens". Salvien de Marseille, 4.50, op cit.

\section{REFERÊNCIAS BIBLIOGRÁFICAS}

FONTES

EUSÉBIO DE CESARÉIA. História Eclesiástica. São Paulo: Fonte Editorial, 2005.

GAUDEMENT, Jean (org). Les canons des conciles mérovingiens (VI-VII siècles). Paris: Cerf, 1989

JEAN CASSIEN. Institutions cénobitiques. Paris: Cerf, 2001.

JEAN CASSIEN. Conférences. Paris: Cerf, 1959, 3 vol.

HILAIRE D'ARLES. Vie de Saint Honorat. Paris: Cerf, 2008.

SAINT EUCHER DE LYON. Du mépris du monde et de la philosophie du siècle. Paris: Nouvelles Éditions Latines, 1950. 
SALVIEN DE MARSEILLE. “À I'Église”. Oeuvres. Paris: Cerf, 1971-1972.

\section{BibliogRAFIA}

CARRUTHERS, Mary. A técnica do pensamento. Campinas: Editora da Unicamp, 1998.

CHADWICK, Owen. Euladius of Arles. Journal of theological studies, 46, 1945.

DE VOGÜÉ, Adalbert. "Monachisme et Église dans la pensée de Cassien". Paris: Théologie de la vie monastique: études sur la tradition patristique, 1961

DE VOGÜÉ, Adalbert. Histoire littperaire du mouvement monastique: I'essor de la litterature lérinienne et les écrits contemporains (420-500). Paris: Cerf, 2003.

GOODRICH, Richard. Contextualizing Cassian: aristocrats, ascetism, and reformation in fifth-century Gaul. Oxford: Oxford University Press, 2007.

MARROU, Henri-Irinée. "Doctrine et discipline dans la langue des pères". Bulletin du Cange, 9, 1934, p. 5-25.

MATHISEN, R. Ecclesiastical factionalism and religious controversy in fifthcentury Gaul. Washington: The Catholic University of America Press, 1989

NOUAILHAT, René. Saints et patrons. Paris: Belles Léttres, 1988, p. 170.

STEWART, Columba Cassian, the monk. Oxford: Oxford University Press, 1998

VAUCHEZ, André. A espiritualidade na Idade Média Ocidental. Rio de Janeiro: Jorge Zahar, 1995.

WEISS, Jean-Pierre. "Le statut du prédicateur et les instruments de la prédication dans la Provence du Ve. siècle". In: M. Lauwers; R-M Dessi. La parole du prédicateur (V-XV siècles). Nice: Z Éditions. Centre d’Études Médiévales. Faculté des Lettres, Arts et Sciences Humaines, 1997. 